\title{
PELUANG PENGEMBANGAN PERIKANAN TANGKAP DI PROVINSI SUMATERA SELATAN
}

\author{
(The Development Opportunity of Catch Fishery in \\ the Province of Southern Sumatera)
}

Septifitri ${ }^{1}$, Daniel R Monintja ${ }^{2}$, Sugeng Hari Wisudo ${ }^{2}$ dan Sulaeman Martasuganda ${ }^{2}$

\begin{abstract}
South Sumatera province since 2000, began managing the fishery resources separately with the Province of Bangka Belitung. Bangka Belitung contribution in the fisheries sector of the South Sumatera province in 1999 by $72 \%$. Based on these conditions, then do research on fisheries development opportunities in the surrounding waters of South Sumatera. This research was conducted in February 2006 until July 2006 in two Regency namely Komiring Ogan Ilir and Banyuasin Regency. The results showed that the leading commodities in the province of South Sumatera is shrimp, crab, marine catfish (Arius thalassinus), and wolf herring (Chirosentrus dorab). This leading commodities still have a great opportunity to be developed for their utilization rates still ranged between $58,42 \%-$ 66,77\% Fishing gear priority based on the analysis of MCA (multy Critical Analysis) with considering the biological aspects, technical, social and economic is trammelnet, drift gillnet and Stationary-bamboo lift net.
\end{abstract}

Keywords: fishery resoursec, catch fishery, leading commodities

\begin{abstract}
ABSTRAK
Provinsi Sumatera Selatan sejak tahun 2000 mulai mengelola sumberdaya perikanan secara terpisah dengan Provinsi Bangka Belitung. Kontribusi Bangka Belitung di sektor perikanan terhadap Provinsi Sumatera Selatan pada tahun 1999 sebesar 72\%. Berdasarkan kondisi tersebut, maka dilakukan penelitian terhadap peluang pengembangan perikanan di sekitar perairan Sumatera Selatan. Penelitian ini dilakukan pada bulan Februari 2006 sampai Juli 2006 di dua kabupaten yaitu Kabupaten Ogan Komiring Ilir dan Kabupaten Banyuasin. Hasil penelitian menunjukkan bahwa komoditi unggulan di provinsi Sumatera Selatan adalah udang, kepiting, manyung dan golok-golok. Komoditi unggulan ini masih memiliki peluang yang besar untuk dikembangkan karena tingkat pemanfaatannya masih berkisar antara 58,42\% - 66,77\%. Jenis alat tangkap trammelnet, jarring insang hanyut dan bagan tancap merupakan alat tangkap prioritas terbaik untuk dikembangkan berdasarkan analisis dengan metode scoring dengan mempertimbangkan aspek biologi, teknis, sosial dan ekonomi.
\end{abstract}

Kata kunci : sumberdaya perikanan, perikanan tangkap, komoditi unggulan

\section{PENDAHULUAN}

Sektor kelautan dan perikanan di Provinsi Sumatera Selatan merupakan salah satu sektor unggulan karena memiliki beberapa keunggulan komparatif dan kompetitif. Oleh karena itu, keberhasilan pembangunan sektor kelautan dan perikanan diharapkan mampu menyediakan bahan pangan (protein hewani) bagi masyarakat, meningkatkan pendapatan nelayan, membuka lapangan kerja serta meningkatkan pendapatan daerah dan devisa negara.

Dalam suasana lingkungan strategis yang berubah dengan cepatnya serta mengantisipasi perubahan eksternal dan internal, maka visi pembangunan kelautan dan perikanan di Sumatera Selatan adalah sumberdaya kelautan dan perikanan beserta jasa-jasa lingkungan yang terdapat di dalamnya merupakan sumber penghidupan dan pembangunan ekonomi dan sosial budaya yang harus dikelola secara berkelanjutan, guna meningkatkan pendapatan nelayan.

Terpisahnya Provinsi BangkaBelitung dari Provinsi Sumatera Selatan pada tahun 2000 memberikan dampak yang sangat besar terhadap perkembangan perikanan tangkap di Provinsi Sumatera Selatan. Hal ini dikarenakan kontribusi yang sangat besar dari BangkaBelitung sebelum berpisah dari Provinsi Sumatera Selatan.

\footnotetext{
${ }_{2}^{1}$ Staf Kementerian Kelautan dan Perikanan

${ }^{2}$ Staf pengajar Departemen Pemanfaatan Sumberdaya Perikanan, FPIK- IPB
} 
Sektor kelautan dan perikanan di Propinsi Sumatera Selatan merupakan salah satu sektor unggulan karena memiliki beberapa keunggulan komparatif dan kompetitif. Oleh karena itu, keberhasilan pembangunan sektor kelautan dan perikanan diharapkan mampu menyediakan bahan pangan (protein hewani) bagi masyarakat, meningkatkan pendapatan nelayan, membuka lapangan kerja serta meningkatkan pendapatan daerah dan devisa negara.

Dalam suasana lingkungan strategis yang berubah dengan cepatnya serta mengantisipasi perubahan eksternal dan internal, maka visi pembangunan kelautan dan perikanan di Sumatera Selatan adalah sumberdaya kelautan dan perikanan beserta jasa-jasa lingkungan yang terdapat di dalamnya merupakan sumber penghidupan dan pembangunan ekonomi dan sosial budaya yang harus dikelola secara berkelanjutan, guna meningkatkan pendapatan nelayan.

Terpisahnya Provinsi Bangka-Belitung dari Provinsi Sumatera Selatan pada tahun 2000 memberikan dampak yang sangat besar terhadap perkembangan perikanan tangkap di Provinsi Sumatera Selatan. Hal ini dikarenakan kontribusi yang sangat besar dari Bangka-Belitung sebelum berpisah dari Provinsi Sumatera Selatan. Berdasarkan data statistik perikanan Provinsi Sumatera Selatan tahun 1999 menunjukkan bahwa kontribusi BangkaBelitung di sektor produksi perikanan (Tabel 1) sebesar $72 \%$. Besarnya kontribusi ini juga mempengaruhi sektor lainnya seperti Rumah Tangga Perusahaan (RTP) sebesar $84,04 \%$, perahu/kapal $82,83 \%$, dan nilai produksi 66,36. Luas laut yang dapat dikelola dan dimanfaatkan untuk usaha penangkapan di Provinsi Sumatera Selatan kurang lebih $37.000 \mathrm{~km}^{2}$. Berdasarkan hasil kajian Komisi Nasional Sumberdaya Ikan Laut Tahun 2002 untuk Wilayah Pengelolaan Perikanan (WPP) di laut Cina Selatan adalah potensi ikan pelagis besar adalah 0,32 ton $/ \mathrm{km}^{2}$, pelagis kecil 2,26 ton $/ \mathrm{km}^{2}$, demersal 1,2 ton $/ \mathrm{km}^{2}$, dan udang 0,18 ton $/ \mathrm{km}^{2}$. Sehingga total potensi yang ada di wilayah pengelolaan tersebut adalah 146.520 ton dengan pembagian ikan pelagis besar sebanyak 11.840 ton, pelagis kecil 83.620 ton, ikan demersal 44.400 ton dan udang 6.660 ton. Berdasarkan hasil tersebut, maka pemanfaatan sumberdaya ikan laut di WPP tersebut oleh Provinsi Sumatera Selatan baru sekitar 33,95 \%.

Pengembangan usaha perikanan tangkap secara umum bisa dilakukan dengan peningkatan produksi dan produktivitas usaha perikanan, yang ditujukan untuk meningkatkan pendapatan nelayan, produk domestik bruto, devisa negara, pendapatan asli daerah, peme-nuhan gizi masyarakat dan penyerapan tenaga kerja, tanpa menganggu dan merusak kelestarian sumberdaya perikanan.

Beberapa permasalahan yang harus diperhatikan saat ini di Propinsi Sumatera Selatan dengan kondisi wilayah yang memiliki potensi perikanan yang cukup besar, namun pemanfaatan dari potensi ini belum optimal yaitu informasi sumberdaya yang ada di sekitar wilayah pengelolaan Provinsi Sumatera Selatan yang belum optimal, informasi tentang teknologi yang efektif dan efisien, terjadinya persaingan areal penangkapan antara alat tangkap aktif dan pasif, pengawasan dan penegakan hukum belum dilaksanakan secara efektif, prasarana pelabuhan belum memadai, kemampuan nelayan untuk investasi sendiri masih lemah dan lemahnya posisi tawar dari nelayan dalam melaksaksanakan pemasaran.

Adapun tujuan dari penelitian ini adalah (1). mengestimasi peluang pengembangan; (2). menentukan komoditi unggulan; dan (3). menentukan jenis alat tangkap unggulan. Secara keseluruhan penelitian ini merupakan bagian dari penelitian secara menyeluruh dalam disertasi. Adapun kerangka pemikiran penelitian ini ditunjukkan pada Gambar 1. 
Tabel 1. Kontribusi perikanan Bangka Belitung terhadap produksi perikanan di Provinsi Sumatera Selatan Tahun 1999

\begin{tabular}{|c|c|c|c|c|c|c|}
\hline \multirow[b]{2}{*}{ Wilayah } & \multicolumn{4}{|c|}{ Kelompokikan } & \multirow[b]{2}{*}{ Jumlah } & \multirow[b]{2}{*}{ Persentase } \\
\hline & Demersal & Pelagis & $\begin{array}{c}\text { Binatang } \\
\text { berkulit keras }\end{array}$ & $\begin{array}{c}\text { Binatang } \\
\text { berkulit lunak }\end{array}$ & & \\
\hline Bangka Belitung & \multirow{4}{*}{$22.993,1$} & \multirow{4}{*}{$84.574,2$} & \multirow{4}{*}{$3.504,3$} & \multirow{4}{*}{$2.907,9$} & \multirow{4}{*}{113.980} & \multirow{4}{*}{72} \\
\hline a. Kab. Bangka & & & & & & \\
\hline b. Kab. Pangkal Pinang & & & & & & \\
\hline c. Kab. Belitung & & & & & & \\
\hline Sumatera Selatan & \multirow{3}{*}{$14.182,9$} & \multirow{3}{*}{$25.771,3$} & \multirow{3}{*}{$5.031,0$} & \multirow{3}{*}{220,2} & \multirow{3}{*}{45.205} & \multirow{3}{*}{28} \\
\hline a. Ogan Komiring llir & & & & & & \\
\hline b. Banyuasin & & & & & & \\
\hline Total Tahun 1999 (bergabung) & $37.176,0$ & $110.345,5$ & $8.535,3$ & $3.128,1$ & 159.185 & 100 \\
\hline
\end{tabular}

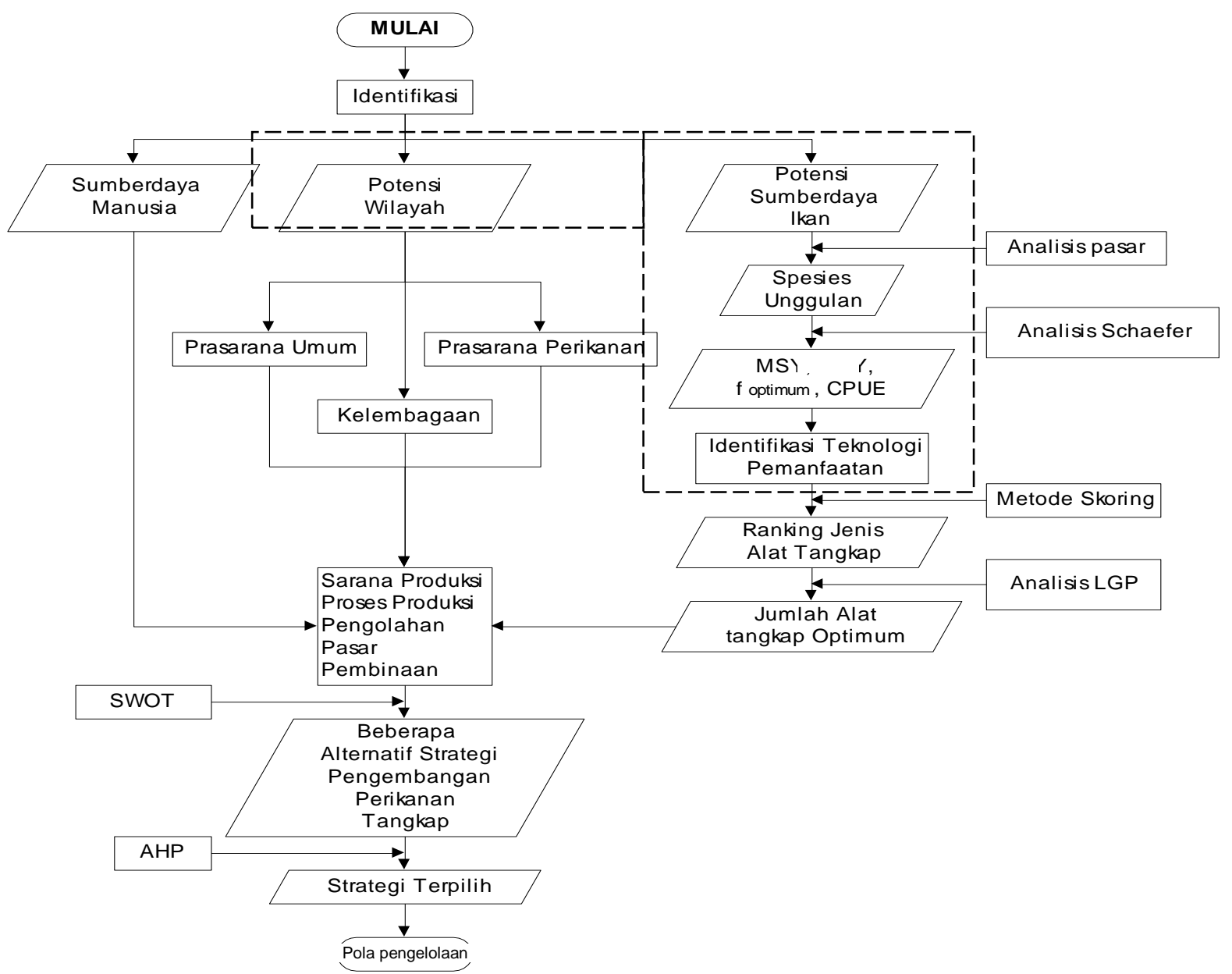

Gambar 1. Kerangka Pemikiran

\section{METODE PENELITIAN}

\subsection{Lokasi Penelitian}

Penelitian dilakukan di Provinsi Sumatera Selatan tepatnya di Kab. Banyuasin dan Ogan Komiling Ilir, pengambilan data lapangan dilaksanakan pada bulan Februari 2006 s/d Juli 2006.

\subsection{Pengumpulan Data}

Data yang digunakan berupa data primer dan data sekunder. Data primer diperoleh dari pengamatan langsung di lapangan serta wawancara dengan nelayan, pengumpul ikan, perusahan-perusahan, pemerintah (sebagai pengambil kebijakan) serta pihak terkait lainnya. Sedangkan data sekunder diperoleh dari data-data statistik Dinas Kelautan dan Perikanan, BPS dan Instansi-instansi terkait lainnya. 


\subsection{Analisis Data}

\subsubsection{Analisis Potensi Sumberdaya Ikan}

Keanekaragaman jenis alat tangkap yang digunakan di suatu perairan memungkinkan suatu spesies ikan tertangkap pada beberapa jenis alat tangkap. Gulland (1983), menyatakan jika di suatu daerah perairan terdapat berbagai jenis alat tangkap yang dipakai, maka salah satu alat tersebut dapat dipakai sebagai alat tangkap standar, sedangkan alat tangkap yang lainnya dapat distandarisasikan terhadap alat tangkap tersebut. Alat tangkap yang ditetapkan sebagai alat tangkap standard mempunyai faktor daya tangkap atau fishing power indeks $(F P I)=1$ (Tampubolon dan Sutedjo, 1983). Jenis alat tangkap lainnya dapat dihitung nilai FPI dengan membagi nilai catch per unit effort (CPUE) dengan CPUE alat tangkap standard. Niliai FPI ini kemudian digunakan untuk mencari upaya standard yaitu dengan mengalikan nilai FPI dengan upaya penangkapan jenis alat tangkap yang dianalisis.

$$
\begin{aligned}
& C P U E_{s}=\frac{C_{s}}{F_{s}} \\
& C P U E_{i}=\frac{C_{i}}{F_{i}} \\
& F P I_{s}=\frac{C P U E_{s}}{C P U E_{s}}=1 \\
& F P I_{i}=\frac{C P U E_{i}}{C P U E_{s}}
\end{aligned}
$$

Standard Effort $=\Sigma F P I_{i} \times \Sigma E$.

dimana :

$C P U E_{s}=$ Hasil tangkapan per upaya penangkapan alat tangkap standar

$C P U E_{\mathrm{i}}=$ Hasil tangkapan per upaya penangkapan alat tangkap $i$

$E \quad=$ Upaya dengan alat tangkap $i$

$C_{s} \quad=$ Jumlah tangkapan jenis alat tangkap standar

$\mathrm{Ci}$ =Jumlah tangkapan jenis alat tangkap $i$

$F_{s} \quad=$ Jumlah upaya jenis alat tangkap standar

$F_{i} \quad=$ Jumlah upaya jenis alat tangkap $i$

$F P I_{s}=$ Faktor daya tangkap jenis alat tangkap standar

$F P I_{i} \quad=$ Faktor daya tangkap jenis alat tangkap $i$

\subsubsection{Metode Surplus Produksi}

Salah satu metode pendugaan stok ikan adalah metode surplus produksi. Metode ini digunakan dalam perhitungan potensi lestari maksimum (MSY) dan upaya penangkapan optimum dengan cara menganalisis hubungan upaya penangkapan $(E)$ dengan hasil tangkapan persatuan upaya (CPUE).

Data yang digunakan dalam perhitungan tersebut adalah data hasil tangkapan dan upaya penangkapan dari statistik Dinas Kelautan dan Perikanan Propinsi Sumatera Selatan tahun 2000 sampai dengan 2007. Analisis data menggunakan pendekatan Model Schaefer. Berdasarkan parameter-parameter model surplus produksi yang diperoleh, kemudian dilakukan penyusunan fungsi produksi. Hubungan hasil tangkapan dengan upaya penangkapan adalah :

$C=a E-b E^{2}$

Hubungan antara Catch Per Unit Effort (CPUE) dengan upaya penangkapan adalah : $C P U E=a-b E$

Perhitungan upaya penangkapan optimum (Eopt) dilakukan dengan menurunkan persamaan (3) sama dengan 0 (nol).

$F_{\text {opt }}=a / 2 b$

Potensi lestari (MSY) diperoleh dengan memasukan persamaan (3) ke persamaan (4) sehingga kondisi MSY adalah : $M S Y=a^{2} / 4 b$ dengan :

$a$ = konstanta, intersep (titik perpotongan garis regresi dengan sumbu y)

$b \quad=$ slope (kemiringan dari garis regresi)

c $\quad=$ catch per unit effort

$M S Y=$ maximum sustainable yield (potensi lestari)

\subsubsection{Metode Skoring}

Metode skoring dapat digunakan untuk penilaian kriteria yang mempunyai satuan berbeda. Skoring diberikan kepada nilai terendah sampai nilai tertinggi. Untuk menilai semua kriteria atau aspek digunakan nilai tukar, sehingga semua nilai mempunyai standard yang sama. Unit usaha yang memperoleh nilai tertinggi berarti lebih baik daripada yang lain demikian pula sebaliknya. Untuk menghindari pertukaran yang terlalu banyak, maka digunakan fungsi nilai yang menggambarkan preferensi pengambil keputusan dalam menghadapi kriteria majemuk. 
Standardisasi dengan fungsi nilai dapat dilakukan dengan menggunakan rumus dari Mangkusubroto dan Trisnadi (1985) sebagai berikut :

$V(X)=\frac{X-X_{0}}{X_{1}-X_{0}}$

$V(A)=\sum_{i=1}^{n} V i(X i) \quad \mathrm{i}=1,2,3, \ldots, n$

dengan :

$V(X)=$ Fungsi nilai dari variabel $X$

$X=$ Nilai variabel $X$

$X_{1}=$ Nilai tertinggi pada kriteria $X$

$X_{0}=$ Nilai terendah pada kriteria $X$

$V(A)=$ Fungsi nilai dari alternatif $A$

$V i(X i)=$ Fungsi nilai dari alternatif pada kriteria ke-i

Karena $V$ adalah fungsi yang mencerminkan preferensi pengambil keputusan, maka alternatif yang terbaik adalah alternatif yang memberikan nilai $V(X)$ tertinggi merupakan alat tangkap ikan yang terpilih untuk dikembangkan diperairan Sumatera Selatan.

\section{HASIL DAN PEMBAHASAN}

\subsection{Perikanan Tangkap di Provinsi Sumatera Selatan}

Berdasarkan data statistik tahun 2001-2007 jumlah rumah tangga

perikanan perikanan Provinsi Sumatera Selatan secara umum mengalami peningkatan dari tahun 2001-2007 sebesar 3.941 dan 7.159. Berdasarkan kategori usaha terlihat bahwa jenis kapal motor memiliki jumlah RTP tertinggi dibandingkan dengan RTP lainnya. Pada kategori kapal motor terlihat juga bahwa kapal motor < 30 GT memiliki jumlah RTP terbanyak pada tahun 2007 yaitu 3.957 unit. Jumlah nelayan perikanan laut di Propinsi Sumatera Selatan ditunjukkan pada Tabel 2.

Kategori perahu/kapal yang paling banyak digunakan di Provinsi Sumatera Selatan adalah kapal dengan tonase < 30 GT sebanyak 4.797 unit. Selanjutnya tanpa motor merupakan jumlah armada kedua yang terbanyak yaitu 1.769 unit. Secara umum jumlah armada perikanan yang ada di Provinsi Sumatera Selatan pada kurun waktu tahun 2001-2007 mengalami peningkatan yaitu pada tahun 2001 sebanyak 4030 unit dan pada tahun 2007 bertambah menjadi 6.864 unit. Data jumlah armada penangkapan yang beroperasi di wilayah Provinsi Sumatera Selatan disajikan pada Tabel 3.

Tabel 2. Jumlah RTP menurut kategori usaha di Provinsi Sumatera Selatan

\begin{tabular}{|l|l|r|r|r|r|r|r|r|}
\hline \multirow{2}{*}{ Kategori Usaha } & \multicolumn{9}{|c|}{ Tahun } \\
\cline { 2 - 10 } & & 2001 & 2002 & 2003 & 2004 & 2005 & 2006 & 2007 \\
\hline \multirow{4}{*}{ Perahu tanpa motor } & Kecil & 371 & 380 & 413 & 465 & 508 & 550 & 580 \\
\cline { 2 - 10 } & Sedang & 312 & 315 & 664 & 744 & 813 & 882 & 1050 \\
\cline { 2 - 10 } & Besar & 185 & 132 & 161 & 161 & 176 & 191 & 203 \\
\hline \multirow{3}{*}{ Motor tempel } & & 83 & 86 & 221 & 225 & 247 & 268 & 330 \\
\hline \multirow{5}{*}{ Kapal motor } & $<5$ GT & 2405 & 2412 & 2495 & 2718 & 3073 & 3427 & 3957 \\
\cline { 2 - 10 } & $5-10$ GT & 407 & 417 & 389 & 420 & 472 & 524 & 604 \\
\cline { 2 - 10 } & $10-20$ GT & 46 & 52 & 214 & 230 & 263 & 295 & 307 \\
\cline { 2 - 10 } & $20-30$ GT & 132 & 135 & 45 & 47 & 61 & 74 & 110 \\
\cline { 2 - 10 } & $30-50$ GT & 0 & 0 & 12 & 12 & 14 & 16 & 18 \\
\hline & & 3941 & 3929 & 4614 & 5022 & 5624.5 & 6227 & 7159 \\
\hline
\end{tabular}

Sumber : Statistik Perikanan Sumatera Selatan Tahun 2000-2007 
Tabel 3. Jumlah perahu/kapal perikanan menurut jenis atau ukuran perahu di Provinsi Sumatera Selatan sejak tahun 2000-2007

\begin{tabular}{|l|r|r|r|r|r|r|r|}
\hline & \multicolumn{7}{|c|}{ Tahun } \\
\cline { 2 - 8 } \multicolumn{1}{l|}{ Kategori Perahu/kapal } & 2001 & 2002 & 2003 & 2004 & 2005 & 2006 & 2007 \\
\hline Perahu : & & & & & & & \\
\hline a. Tanpa Motor & 903 & 827 & 1240 & 1370 & 1497 & 268 & 1769 \\
\hline b. Motor Tempel & 100 & 86 & 221 & 225 & 247 & 268 & 279 \\
\hline Kapal Motor: & & & & & & & \\
\hline a. <30 GT & 3027 & 3016 & 3362 & 3634 & 3977 & 4320 & 4797 \\
\hline b. > 30 GT & - & - & 12 & 12 & 14 & 16 & 19 \\
\hline Jumlah & 4030 & 3929 & 4835 & 5241 & 5734 & 4872 & 6864 \\
\hline
\end{tabular}

Sumber : Statistik Perikanan Sumatera Selatan Tahun 2000-2007

Alat tangkap yang banyak dioperasikan di perairan oleh nelayan Provinsi Sumatera Selatan, terdiri dari enam kelompok yaitu seine net, gillnet, lift net, rawai, trap, dan alat pengumpul kerang. Jumlah alat tangkap di perairan Sumatera Selatan pada tahun 2001-2007 mengalami peningkatan yaitu 4.537 unit pada tahun 2001 dan 7.801 pada tahun 2007 . Peningkatan ini seiring dengan peningkatan jumlah armada dan volume penangkapan ikan di sekitar perairan Sumatera Selatan setelah berpisah dengan Provinsi Bangka Belitung.

Jenis alat tangkap paling banyak digunakan oleh nelayan di sekitar Sumatera Selatan adalah jenis jaring insang (Gill-net, Trammel-net, jaring kepiting dan jaring cawang). Jenis jaring ini sangat populer digunakan sampai pada Tahun 2007, hal ini dikarenakan oleh jenis target spesies yang memungkinkan untuk ditangkap menggunakan jenis alat tangkap ini di sekitar perairan Sumatera Selatan. Data jumlah alat tangkap yang dioperasikan oleh nelayan Sumatera Selatan disajikan pada Tabel 4.

\subsection{Produksi Perikanan Tangkap di Sumatera Selatan}

Produksi perikanan tangkap secara keseluruhan berdasarkan jenis alat tangkap dan jenis ikan di Provinsi Sumatera Selatan di tunjukkan pada Tabel 5 dan 6 .

Tabel 4. Perkembangan jumlah alat tangkap perikanan laut (unit) menurut jenis alat tangkap di Provinsi Sumatera Selatan

\begin{tabular}{|r|l|r|r|r|r|r|r|r|}
\hline \multirow{2}{*}{ No. Alat Tangkap } & \multicolumn{9}{|c|}{ Tahun } \\
\cline { 3 - 9 } & & 2001 & 2002 & 2003 & 2004 & 2005 & 2006 & 2007 \\
\hline 1. & Payang & 98 & 139 & 179 & 179 & 208 & 236 & 258 \\
\hline 2. & Jaring insang hanyut & 513 & 1008 & 408 & 422 & 434 & 446 & 480 \\
\hline 3. & Jaring insang tetap & 196 & 202 & 825 & 854 & 822 & 789 & 696 \\
\hline 4. & Jaring lingkar & 101 & 94 & 86 & 86 & 91 & 95 & 101 \\
\hline 5. & Jaring klitik & 345 & 403 & 471 & 478 & 467 & 457 & 407 \\
\hline 6. & Tramel net & 696 & 712 & 856 & 870 & 844 & 818 & 789 \\
\hline 7. & Bagan tancap & 570 & 580 & 648 & 717 & 724 & 731 & 760 \\
\hline 8. & Serok & 260 & 39 & 251 & 251 & 271 & 291 & 398 \\
\hline 9. & Jaring angkat lainnya & 146 & 395 & 647 & 658 & 729 & 800 & 764 \\
\hline 10. & Pancing & 777 & 751 & 1042 & 1064 & 1186 & 1308 & 1222 \\
\hline 11. & Sero & 194 & 204 & 356 & 577 & 619 & 661 & 769 \\
\hline 12. & Jermal & 234 & 238 & 244 & 244 & 265 & 285 & 293 \\
\hline 13. & Alat perangkap lainnya & 535 & 802 & 411 & 688 & 742 & 795 & 736 \\
\hline 14. & Alat pengumpul kerang & 106 & 15 & 282 & 295 & 173 & 51 & 128 \\
\hline & & 4537 & 5581 & 6706 & 7383 & 7572 & 7762 & 7801 \\
\hline
\end{tabular}

Sumber : Statistik Perikanan Sumatera Selatan Tahun 2000-2007 
Tabel 5. Produksi perikanan tangkap menurut jenis alat tangkap di Provinsi Sumatera Selatan Tahun 2001-2007

\begin{tabular}{|c|c|c|c|c|c|c|c|c|}
\hline \multirow{2}{*}{ No. } & \multirow{2}{*}{ Alat tangkap } & \multicolumn{7}{|c|}{ Tahun } \\
\hline & & 2001 & 2002 & 2003 & 2004 & 2005 & 2006 & 2007 \\
\hline 1. & Payang & 259.80 & 372.30 & 190.80 & 203.30 & 100.80 & 128.50 & 197.50 \\
\hline 2. & Jaring insang hanyut & 11972.30 & 12751.90 & 12348.00 & 12675.20 & 11626.10 & 8287.60 & 8156.80 \\
\hline 3. & Jaring insang tetap & 132.70 & 203.00 & 6652.40 & 6869.70 & 5537.90 & 4519.60 & 1792.00 \\
\hline 4. & Jaring lingkar & 472.70 & 616.10 & 695.70 & 706.90 & 364.00 & 467.60 & 587.25 \\
\hline 5. & Jaring klitik & 3090.80 & 3340.20 & 3360.60 & 3454.40 & 1777.40 & 2265.90 & 2860.15 \\
\hline 6. & Trammel net & 6638.90 & 7102.10 & 4186.40 & 4326.80 & 2226.50 & 2856.40 & 4348.00 \\
\hline 7. & Bagan tancap & 9532.00 & 10150.40 & 9285.60 & 9562.40 & 8443.00 & 6233.80 & 8461.00 \\
\hline 8. & Serok & 65.30 & 91.90 & 94.40 & 104.60 & 120.50 & 101.20 & 113.88 \\
\hline 9. & Jaring angkat & 29.60 & 39.60 & 40.70 & 41.90 & 22.00 & 27.90 & 48.00 \\
\hline 10. & $\begin{array}{l}\text { Pancing + Pancing } \\
\text { Tonda }\end{array}$ & 5938.70 & 6391.30 & 6053.70 & 6252.50 & 6224.10 & 4104.20 & 3267.80 \\
\hline 11. & Sero & 3079.90 & 3272.30 & 3141.40 & 3240.50 & 1669.60 & 2144.40 & 2098.30 \\
\hline 12. & Alat perangkap lainnya & 4349.00 & 4660.30 & 3953.70 & 4070.10 & 2905.65 & 2683.10 & 1264.00 \\
\hline 13. & Alat pengumpul kerang & 326.80 & 360.90 & 549.90 & 563.70 & 290.10 & 369.80 & 781.50 \\
\hline 14. & Jenis alat lainnya & 303.2 & 371.90 & 1913.4 & 1968.7 & 3454.90 & 1294.4 & 2666.90 \\
\hline & Jumlah & 46191.70 & 49724.20 & 52466.70 & 54040.70 & 44762.55 & 35484.40 & 36643.08 \\
\hline
\end{tabular}

Sumber : Statistik Perikanan Sumatera Selatan Tahun 2001-2007

Pada tabel 5 di atas dapat dilihat bahwa secara umum terjadi trend peningkatan produksi perikanan tangkap sepanjang periode 2001-2004. Sedangkan pada tahun 2005-2006, terjadi penurunan produksi bila dibandingkan dengan tahun sebelumnya. Kemudian secara perlahanlahan naik kembali pada tahun 2007 dengan produksi mencapai 36643,08 ton.

Peningkatan produksi pada tahun 2001-2004 disebabkan oleh meningkatnya jumlah alat tangkap yaitu 4.537 unit pada tahun 2001 menjadi 7.383 unit pada tahun 2004, sebanding dengan mening-katnya trip penangkapan pada tahun 2001 yaitu 774.343 menjadi 1.023 .260 pada tahun 2004.

Penurunan produksi pada tahun 2005 dan 2006 adalah sebagai dampak kenaikan harga BBM yang terjadi pada tahun 2005, sehingga ada sebahagian alat tangkap yang tidak beroperasi, ini terlihat dari penurunan jumlah trip pada tahun 2004 yaitu 1.023.260 menurun jadi 894.750 pada tahun 2005, produksi berdasarkan jenis ikan hasil tangkapan tahun 2001-2007 ditunjukkan pada tabel 6 .

Kapal perikanan yang beroperasi di sekitar perairan Sumatera Selatan, pada umumnya dilakukan dengan satu kali trip (one day fishing). Berdasarkan pada Tabel 7, terlihat pula bahwa jumlah trip penangkapan ikan terendah pada tahun 2007 adalah jaring lingkar. Secara keseluruhan trip penangkapan ikan di Provinsi Sumatera Selatan mengalami peningkatan setiap tahunnya. Dimana, pada tahun 2001 jumlah trip sebesar 774.343 kali dan pada tahun 2007 sebanyak 982.386 kali dalam setahun.

Tingkat produktivitas merupakan faktor yang mempengaruhi pendapatan nelayan di samping tingkat harga ikan hasil tangkapan. Harga ikan mengalami fluktuasi di provinsi Sumatera Selatan. Fluktuasi ini dipengaruhi oleh kondisi ekonomi negara, kebijakan pemerintah dan ketersediaan sumberdaya yang terbatas pada musimmusim tertentu. Harga ikan per jenis ikan ditunjukkan secara lengkap dan jelas pada Tabel 8.

Nilai produksi perikanan tangkap berdasarkan jenis ikan di Provinsi Sumatera Selatan berdasarkan Tabel 9 terlihat mengalami kenaikan dari tahun ke tahun. Pada tahun 2001 nilai produksi perikanan tangkap sebesar Rp. 296.791.000.000,- dan Rp. 374.185.200.000,- pada tahun 2007. Secara jelas nilai produksi perikanan tangkap di Provinsi Sumatera Selatan ditunjukkan pada Tabel 9. 
Tabel 6. Produksi perikanan tangkap menurut jenis ikan di Provinsi Sumatera Selatan Tahun 2001-2007

\begin{tabular}{|c|c|c|c|c|c|c|c|c|}
\hline \multirow{2}{*}{ Kategori } & \multirow{2}{*}{ Jenis Ikan } & \multicolumn{7}{|c|}{ Tahun } \\
\hline & & 2001 & 2002 & 2003 & 2004 & 2005 & 2006 & 2007 \\
\hline \multirow{9}{*}{ Demersal } & Sebelah & 483.80 & 535.30 & 563.20 & 579.30 & 598.20 & 380.10 & 486.80 \\
\hline & Peperek & 1460.40 & 1572.60 & 1678.40 & 1727.30 & 1512.50 & 1133.90 & 1284.80 \\
\hline & Manyung & 3316.60 & 3706.80 & 3979.10 & 4481.80 & 2052.50 & 2464.30 & 2161.24 \\
\hline & Gerot-gerot & 1738.70 & 1860.00 & 2035.10 & 2095.00 & 1078.90 & 1375.50 & 1381.30 \\
\hline & Merah & 786.30 & 869.80 & 862.60 & 885.70 & 577.55 & 581.40 & 953.30 \\
\hline & Kakap & 1205.40 & 1357.40 & 1415.80 & 2003.20 & 2252.00 & 958.50 & 1036.60 \\
\hline & Gulamah & 569.30 & 707.60 & 722.40 & 1123.70 & 882.20 & 487.30 & 519.53 \\
\hline & Cucut & 2012.80 & 2187.00 & 2320.60 & 2220.80 & 1872.80 & 1566.70 & 1481.27 \\
\hline & Pari & 2180.70 & 2326.10 & 2266.90 & 2751.70 & 2001.20 & 1531.20 & 1344.10 \\
\hline \multirow{14}{*}{ Pelagis } & Kuro & 216.60 & 301.00 & 351.00 & 494.90 & 185.50 & 236.20 & 423.93 \\
\hline & Layur & 549.70 & 610.90 & 590.00 & 657.40 & 312.40 & 398.10 & 623.83 \\
\hline & Bawal Hitam & 1433.80 & 1600.90 & 1714.40 & 1836.40 & 1608.20 & 1357.70 & 1363.63 \\
\hline & Bawal Putih & 805.00 & 960.40 & 945.70 & 1253.40 & 900.40 & 637.90 & 844.40 \\
\hline & Selar & 1628.80 & 1718.60 & 1946.30 & 1065.00 & 1031.50 & 1315.20 & 1282.07 \\
\hline & Belanak & 1291.10 & 1464.00 & 1529.10 & 1903.00 & 1610.10 & 1032.60 & 1666.07 \\
\hline & Teri & 1638.90 & 1739.20 & 1391.10 & 1431.90 & 1337.40 & 940.00 & 1341.93 \\
\hline & Japuh & 508.70 & 578.80 & 546.90 & 561.80 & 289.20 & 368.60 & 583.00 \\
\hline & Golok-golok & 2422.00 & 2671.20 & 3010.50 & 3666.80 & 1230.00 & 1679.60 & 1723.07 \\
\hline & Kembung & 152.80 & 208.00 & 214.60 & 442.40 & 458.80 & 146.20 & 253.60 \\
\hline & Tenggiri Papan & 1002.60 & 1125.60 & 1044.90 & 1075.50 & 953.90 & 706.10 & 820.00 \\
\hline & Tenggiri & 813.70 & 892.70 & 852.10 & 876.10 & 651.00 & 574.80 & 691.23 \\
\hline & Tongkol & 431.00 & 514.20 & 503.70 & 516.60 & 466.10 & 339.20 & 555.67 \\
\hline & Ikan lainnya & 13897.30 & 13748.70 & 14664.00 & 11694.70 & 15280.80 & 10498.20 & 8519.67 \\
\hline \multirow{5}{*}{$\begin{array}{c}\text { Binatang } \\
\text { berkulit keras }\end{array}$} & Rajungan & 470.10 & 700.20 & 1803.80 & 2104.50 & 1008.80 & 1256.10 & 1244.27 \\
\hline & Udang windu & 169.60 & 199.70 & 178.90 & 368.80 & 194.90 & 120.80 & 192.03 \\
\hline & Udang putih & 1863.60 & 2101.20 & 2176.90 & 2580.20 & 1153.80 & 1191.30 & 1294.30 \\
\hline & Udang dogol & 976.30 & 1084.90 & 1104.10 & 1326.90 & 1394.10 & 744.50 & 882.90 \\
\hline & Udang lainnya & 1645.30 & 1803.30 & 1504.70 & 1422.10 & 1577.70 & 1092.60 & 1109.83 \\
\hline Binatang berkulit lunak & Kerang darah & 520.80 & 578.10 & 549.90 & 893.80 & 290.10 & 369.80 & 578.70 \\
\hline \multicolumn{2}{|l|}{ Jumlah } & 46191.70 & 49724.20 & 52466.70 & 54040.70 & 44762.55 & 35484.40 & 36643.08 \\
\hline
\end{tabular}

Sumber : Statistik Perikanan Sumatera Selatan Tahun 2001-2007

Tabel 7.Jumlah trip kapal penangkapan ikan menurut alat penangkapan di Provinsi Sumatera Selatan Tahun 2001-2007

\begin{tabular}{|c|c|c|c|c|c|c|c|c|}
\hline \multirow{2}{*}{ No. } & \multirow{2}{*}{ Alat Tangkap } & \multicolumn{7}{|c|}{ Tahun } \\
\hline & & 2001 & 2002 & 2003 & 2004 & 2005 & 2006 & 2007 \\
\hline 1. & Payang & 6468 & 9418 & 12530 & 12172 & 15847 & 16744 & 15848 \\
\hline 2. & Jaring insang hanyut & 78489 & 67167 & 62424 & 64566 & 25146 & 30888 & 30883 \\
\hline 3. & Jaring insang tetap & 39200 & 40400 & 165000 & 134932 & 116653 & 112038 & 94656 \\
\hline 4. & Jaring lingkar & 17170 & 15895 & 14620 & 14620 & 11390 & 11900 & 13940 \\
\hline 5. & Jaring klitik & 45951 & 11024 & 67581 & 67721 & 78536 & 90723 & 96200 \\
\hline 6. & Tramel net & 139200 & 142400 & 154080 & 137460 & 119848 & 116156 & 107304 \\
\hline 7. & Bagan tancap & 85500 & 87000 & 97200 & 107550 & 78600 & 79650 & 82500 \\
\hline 8. & Serok & 52000 & 7800 & 45180 & 41159 & 38482 & 41322 & 54128 \\
\hline 9. & Jaring angkat lainnya & 12702 & 34365 & 56246 & 57203 & 63380 & 69557 & 66468 \\
\hline 10. & Pancing+Pancing Tonda & 132090 & 144670 & 177140 & 180880 & 150620 & 154360 & 156740 \\
\hline 11. & Sero & 23280 & 24480 & 30604 & 30604 & 57288 & 58124 & 92280 \\
\hline 12. & Alat perangkap lainnya & 107000 & 160400 & 73980 & 108704 & 105293 & 112890 & 127296 \\
\hline 13. & Alat pengumpul kerang & 14840 & 2100 & 39480 & 41300 & 8880 & 9259 & 17920 \\
\hline 14. & Jenis alat lainnya & 20453 & 21765 & 2077 & 24389 & 2787 & 25505 & 26223 \\
\hline & Jumlah & 774343 & 768884 & 1019142 & 1023260 & 894750 & 929115 & 982386 \\
\hline
\end{tabular}

Sumber : Statistik Perikanan Sumatera Selatan Tahun 2001-2007 
Tabel 8. Harga ikan (Rp/Kg) menurut jenis ikan di Provinsi Sumatera Selatan Tahun 20012007

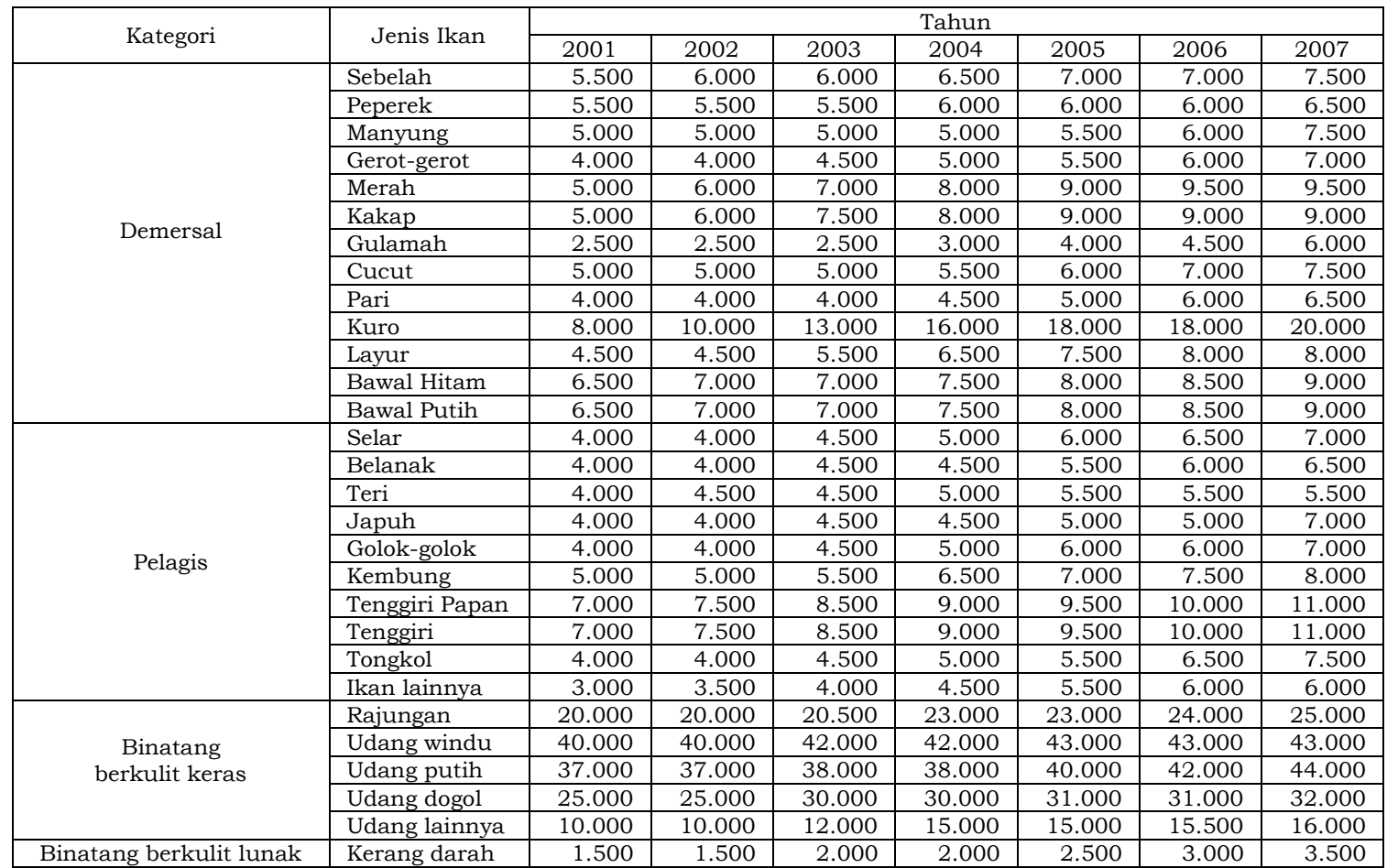

Sumber : Statistik Perikanan Sumatera Selatan Tahun 2001-2007

Tabel 9. Nilai produksi perikanan tangkap di Provinsi Sumatera Selatan Tahun 2001-2007

\begin{tabular}{|c|c|c|c|c|c|c|c|c|}
\hline \multirow{2}{*}{ Kategori } & \multirow{2}{*}{ Jenis Ikan } & \multicolumn{7}{|c|}{ Tahun (Rp. X 1.000.000) } \\
\hline & & 2001 & 2002 & 2003 & 2004 & 2005 & 2006 & 2007 \\
\hline \multirow{13}{*}{ Demersal } & Sebelah & 2660,9 & 3211,8 & 3379,2 & 3765,5 & 4187,4 & 2660,7 & 3651,0 \\
\hline & Peperek & 8032,2 & 8649,3 & 9231,2 & 10363,8 & 9075,0 & 6803,4 & 8351,2 \\
\hline & Manyung & 16583,0 & 18534,0 & 19895,5 & 22409,0 & 11288,8 & 14785,8 & 16209,3 \\
\hline & Gerot-gerot & 6954,8 & 7440,0 & 9158,0 & 10475,0 & 5934,0 & 8253,0 & 9669,1 \\
\hline & Merah & 3931,5 & 5218,8 & 6038,2 & 7085,6 & 5198,0 & 5523,3 & 9056,4 \\
\hline & Kakap & 6027,0 & 8144,4 & 10618,5 & 16025,6 & 20268,0 & 8626,5 & 9329,4 \\
\hline & Gulamah & 1423,3 & 1769,0 & 1806,0 & 3371,1 & 3528,8 & 2192,9 & 3117,2 \\
\hline & Cucut & 10064,0 & 10935,0 & $11603, \mathrm{J0}$ & 12214,4 & 11236,8 & 10966,9 & 11109,5 \\
\hline & Pari & 8722,8 & 9304,4 & 9067,6 & 12382,7 & 10006,0 & 9187,2 & 8736,7 \\
\hline & Kuro & 1732,8 & 3010,0 & 4563,0 & 7918,4 & 3339,0 & 4251,6 & 8478,7 \\
\hline & Layur & 2473,7 & 2749,1 & 3245,0 & 4273,1 & 2343,0 & 3184,8 & 4990,7 \\
\hline & Bawal Hitam & 9319,7 & 11206,3 & 12000,8 & 13773,0 & 12865,6 & 11540,5 & 12272,7 \\
\hline & Bawal Putih & 5232,5 & 6722,8 & 6619,9 & 9400,5 & 7203,2 & 5422,2 & 7599,6 \\
\hline \multirow{10}{*}{ Pelagis } & Selar & 6515,2 & 6874,4 & 8758,4 & 5325,0 & 6189,0 & 8548,8 & 8974,5 \\
\hline & Belanak & 5164,4 & 5856,0 & 6881,0 & 8563,5 & 8855,6 & 6195,6 & 10829,4 \\
\hline & Teri & 6555,6 & 7826,4 & 6260,0 & 7159,5 & 7355,7 & 5170,0 & 7380,6 \\
\hline & Japuh & 2034,8 & 2315,2 & 2461,1 & 2528,1 & 1446,0 & 1843,0 & 4081,0 \\
\hline & Golok-golok & 9688,0 & 10684,8 & 13547,3 & 18334,0 & 7380,0 & 10077,6 & 12061,5 \\
\hline & Kembung & 764,0 & 1040,0 & 1180,3 & 2875,6 & 3211,6 & 1096,5 & 2028,8 \\
\hline & $\begin{array}{l}\text { Tenggiri } \\
\text { Papan }\end{array}$ & 7018,2 & 8442,0 & 8881,7 & 9679,5 & 9062,1 & 7061,0 & 9020,0 \\
\hline & Tenggiri & 5695,9 & 6695,3 & 7242,9 & 7884,9 & 6184,5 & 5748,0 & 7603,6 \\
\hline & Tongkol & 1724,0 & 2056,8 & 2266,7 & 2583,0 & 2563,6 & 2204,8 & 4167,5 \\
\hline & Ikan lainnya & 41691,9 & 48120,5 & 58656,0 & 52626,2 & 84044,4 & 62989,2 & 51118,0 \\
\hline \multirow{5}{*}{$\begin{array}{c}\text { Binatang } \\
\text { berkulit keras }\end{array}$} & Rajungan & 9402,0 & 14004,0 & 36977,9 & 48403,5 & 23202,4 & 30146,4 & 31106,8 \\
\hline & $\begin{array}{l}\text { Udang } \\
\text { windu }\end{array}$ & 6784,0 & 7988,0 & 7513,8 & 15489,6 & 8380,7 & 5194,4 & 8257,4 \\
\hline & Udang putih & 68953,2 & 77744,4 & 82722,2 & 98047,6 & 46152,0 & 50034,6 & 56949,2 \\
\hline & Udang dogol & 24407,5 & 27122,5 & 33123,0 & 39807,0 & 43217,1 & 23079,5 & 28252,8 \\
\hline & $\begin{array}{l}\text { Udang } \\
\text { lainnya }\end{array}$ & 16453,0 & 18033,0 & 18056,4 & 21331,5 & 23665,5 & 16935,3 & 17757,3 \\
\hline $\begin{array}{l}\text { Binatang berkulit } \\
\text { lunak }\end{array}$ & $\begin{array}{l}\text { Kerang } \\
\text { darah }\end{array}$ & 781,2 & 867,2 & 1099,8 & 1787,6 & 725,3 & 1109,4 & 2025,5 \\
\hline \multicolumn{2}{|c|}{ Jumlah } & 296791,0 & 342565,2 & 402854,0 & 475883,7 & 388108,8 & 330832,8 & 374185,2 \\
\hline
\end{tabular}

Sumber : Statistik Perikanan Sumatera Selatan Tahun 2001-2007 


\subsection{Identifikasi sumberdaya ikan ung- gulan}

Kegiatan pemasaran secara umum merupakan salah satu faktor yang mempengarui dalam memacu produksi dan menunjang suksesnya kegiatan usaha perikanan dengan cara pemenuhan kebutuhan akan ikan, baik untuk skala domestik maupun skala ekspor dengan ketentuan harga yang pantas di tingkat nelayan. Sehingga, kesejahteraan nelayan dapat ditingkatkan dengan kegiatan tersebut. Perluasan jangkauan pasar, promosi, penyediaan informasi dan peningkatan pengetahuaan nelayan merupakan faktor-faktor lainnya yang dapat meningkatkan produksi dengan selalu berorientasi pada permintaan pasar. Untuk mengetahui jenis-jenis komoditi yang memiliki potensi dan nilai jual yang baik, dapat dilakukan dengan salah satu cara pendekatan yaitu aspek pemasaran. Oleh karena itu, aspek ini digunakan dalam menentukan komoditi unggulan yang ada di Provinsi Sumatera Selatan.

Metode pada aspek pemasaran tersebut, dilakukan melalui 2 tahapan yaitu pertama, mengiventarisasi semua komoditi yang dianggap memiliki potensi pemasaran yang baik yang diperoleh dari para stakeholder perikanan tangkap di Provinsi Sumatera Selatan. Iventarisasi dari data sekunder juga dijadikan masukan dalam menentukan komoditi unggulan. Selanjutnya, informasi tersebut diseleksi kembali dengan menggunakan metode skoring yang merupakan tahapan ke-dua dari penelitian ini. Seleksi yang dilakukan pada tahap kedua ini, pendekatan terhadap aspek pemasaran dijadikan kriteria seperti nilai produksi, harga, wilayah pemasaran dan nilai tambahnya. Diharapkan dengan melakukan tahapan ini akan diperoleh komoditi unggulan yang benar-benar dapat dijadikan basis dalam pengembangan perikanan tangkap di Provinsi Sumatera Selatan pada masa yang akan datang.

Hasil dari metode skoring tersebut, dipilih 4 (empat) jenis komoditi unggulan berdasarkan fungsi nilai yaitu udang, kepiting, manyung, dan golok-golok. Metode penentuan komoditi unggulan tersebut disajikan pada Tabel 10 .

\subsection{Status dan tingkat pemanfaatan sumberdaya unggulan}

Berdasarkan hasil survei, kosioner, wawancara dengan nelayan dan stake holder di lokasi studi dan berdasarkan hasil analisis yang dilakukan diperoleh 5 (lima) jenis komoditi unggulan yang terdapat di Provinsi Sumatera Selatan sampai tahun 2007. Kelima jenis komoditi tersebut berdasarkan hasil analisis perlu dilakukan analisis besarnya potensi yang ada untuk kelima jenis komoditi unggulan tersebut berdasarkan urutan yaitu udang, kepiting, manyung, bawal dan golok-golok. Estimasi terhadap keberadaan stok ikan di Indonesia dapat dilakukan dengan menggunakan metode sensus/transek, swep area, akustik, surplus production, tagging dan ekstra/ intra-polasi (Azis, 1989 dan Komisi Nasional Pengkajian Stok Sumberdaya Ikan Laut, 1998). Berdasarkan keenam metode yang disajikan tersebut, salah satu metode yaitu metode surplus production merupakan metode yang digunakan dalam penelitian ini. Adapun alasan menggunakan metode tersebut adalah metode tersebut relatif paling murah, cepat dan sederhana dalam pengerjaannya. Adapun kesuksesan dalam menggunakan metode ini terletak pada keakuratan sumber data yang digunakan dalam analisis stok sumberdaya ikan nantinya. Metode ini membutuhkan data time series seperti hasil tangkapan dan upaya penangkapan ikan di tempat pendaratan ikan pada lokasi penelitian. Diakui bahwa metode ini masih terdapat kekurangan seperti masih banyak menggunakan asumsi-asumsi dalam menghitungnya. Penggunaan metode surplus production dengan menerapkan Model Schaefer pada kondisi tertentu, bisa digunakan dalam menghitung dan menentukan batas hasil tangkapan yang diperbolehkan, yaitu untuk memberikan kelonggaran dan keleluasaan bagi nelayan untuk memanfaatkan potensi sumberdaya ikan yang ada (Zulkarnain dan Darmawan, 1997).

Gulland (1983) menyebutkan bahwa suatu stok dianggap sebuah gumpalan besar biomasa dan sama sekali tidak berpedoman atas umur dan ukuran panjang ikan. Dengan pertimbangan bahwa jumlah biomasa stok tetap dan adanya aktivitas usaha perikanan. Dengan demikian dapat diduga bahwa semakin banyak jumlah kapal, maka akan semakin kecil bagian masing-masing kapal. Selanjutnya Widodo (2003) menjelaskan bahwa kejadian tangkap lebih (over fishing) dapat dideteksi dengan suatu kombinasi sejumlah indikator stok, seperti : (i) penurunan hasil tangkapan per unit upaya; (ii) penurunan total hasil tangkapan yang didaratkan; (iii) penurunan 
rata-rata bobot/ukuran ikan; (iv) perubahan struktur umur/struktur ukuran; dan atau (v) perubahan komposisi spesies dalam populasi.
Hasil analisis potensi sumberdaya ikan untuk komoditi unggulan dengan menggunakan metode surplus production dapat ditunjukkan pada Tabel 11.

Tabel 10. Seleksi komoditas unggulan di perairan Sumatera Selatan dengan metode skoring

\begin{tabular}{|c|c|c|c|c|c|c|c|c|c|c|c|}
\hline $\begin{array}{c}\text { Nama } \\
\text { Komoditi } \\
\text { Ikan }\end{array}$ & $\begin{array}{c}\text { Nilai } \\
\text { Produksi } \\
(\mathrm{Rp})\end{array}$ & \begin{tabular}{|c} 
Fungsi \\
Nilai
\end{tabular} & $\begin{array}{l}\text { Harga } \\
(\mathrm{Rp} / \mathrm{Kg})\end{array}$ & $\begin{array}{c}\text { Fungsi } \\
\text { Nilai }\end{array}$ & $\begin{array}{c}\text { Wilayah } \\
\text { Pemasaran }\end{array}$ & \begin{tabular}{|c} 
Fungsi \\
Nilai
\end{tabular} & $\begin{array}{c}\text { Nilai } \\
\text { Tambah }\end{array}$ & $\begin{array}{c}\text { Fungsi } \\
\text { Nilai }\end{array}$ & \begin{tabular}{|c|} 
Nilai \\
Gabungan
\end{tabular} & $\begin{array}{c}\text { Rataan } \\
\text { Fungsi } \\
\text { Nilai } \\
\end{array}$ & Rangking \\
\hline Sebelah & $2,253,512$ & 0.03 & 6,500 & 0.21 & 2 & 0.67 & 1 & 0.50 & 1.405 & 0.351 & 18 \\
\hline Peperek & $6,914,591$ & 0.09 & 5,857 & 0.19 & 1 & 0.33 & 1 & 0.50 & 1.110 & 0.277 & 22 \\
\hline Manyung & $27,570,700$ & 0.35 & 5,571 & 0.18 & 2 & 0.67 & 2 & 1.00 & 2.193 & 0.548 & 3 \\
\hline Gerot-gerot & $6,348,485$ & 0.08 & 5,143 & 0.17 & 1 & 0.33 & 1 & 0.50 & 1.079 & 0.270 & 21 \\
\hline Merah & $4,556,332$ & 0.06 & 7,714 & 0.25 & 2 & 0.67 & 1 & 0.50 & 1.473 & 0.368 & 16 \\
\hline Kakap & $8,618,891$ & 0.11 & 7,643 & 0.25 & 2 & 1.00 & 1 & 0.50 & 1.855 & 0.464 & 7 \\
\hline Gulamah & $1,739,367$ & 0.02 & 3,571 & 0.12 & 2 & 0.67 & 2 & 1.00 & 1.804 & 0.451 & 10 \\
\hline Cucut & $10,472,008$ & 0.13 & 5,857 & 0.19 & 2 & 0.67 & 1 & 0.50 & 1.488 & 0.372 & 12 \\
\hline Pari & $12,798,688$ & 0.16 & 4,857 & 0.16 & 1 & 0.33 & 2 & 1.00 & 1.651 & 0.413 & 11 \\
\hline Kuro & $20,375,114$ & 0.26 & 14,714 & 0.48 & 3 & 1.00 & 1 & 0.50 & 2.232 & 0.558 & 5 \\
\hline Layur & $4,337,045$ & 0.05 & 6,357 & 0.21 & 2 & 0.67 & 1 & 0.50 & 1.427 & 0.357 & 19 \\
\hline Bawal & $6,485,262$ & 0.08 & 7,643 & 0.25 & 2 & 0.67 & 1 & 0.50 & 1.495 & 0.374 & 13 \\
\hline Selar & $4,672,159$ & 0.06 & 5,286 & 0.17 & 2 & 0.67 & 1 & 0.50 & 1.396 & 0.349 & 17 \\
\hline Belanak & $5,186,088$ & 0.07 & 5,000 & 0.16 & 2 & 0.67 & 2 & 1.00 & 1.893 & 0.473 & 6 \\
\hline Teri & $8,862,257$ & 0.11 & 4,929 & 0.16 & 1 & 0.33 & 2 & 1.00 & 1.604 & 0.401 & 14 \\
\hline Japuh & $2,162,512$ & 0.03 & 4,857 & 0.16 & 2 & 0.67 & 2 & 1.00 & 1.851 & 0.463 & 9 \\
\hline Golok-golok & $19,917,307$ & 0.25 & 5,214 & 0.17 & 2 & 0.67 & 2 & 1.00 & 2.086 & 0.521 & 4 \\
\hline Kembung & $1,092,797$ & 0.01 & 6,357 & 0.21 & 2 & 0.67 & 2 & 1.00 & 1.886 & 0.471 & 8 \\
\hline Tenggiri & $6,858,420$ & 0.09 & 8,929 & 0.29 & 2 & 0.67 & 1 & 0.50 & 1.541 & 0.385 & 15 \\
\hline Tongkol & $1,692,210$ & 0.02 & 5,286 & 0.17 & 2 & 0.67 & 1 & 0.50 & 1.359 & 0.340 & 20 \\
\hline Kepiting & $55,031,000$ & 0.69 & 22,214 & 0.72 & 3 & 1.00 & 2 & 1.00 & 3.410 & 0.852 & 2 \\
\hline Udang & $79,549,572$ & 1.00 & 30,946 & 1.00 & 3 & 1.00 & 1 & 0.50 & 3.500 & 0.875 & 1 \\
\hline Kerang darah & $1,195,615$ & 0.02 & 2,286 & 0.07 & 1 & 0.33 & 1 & 0.50 & 0.922 & 0.231 & 23 \\
\hline
\end{tabular}

Keterangan :

$\begin{array}{llll}\text { Untuk wilayah pemasaran: } & 1=\text { Lokal } & 2=\text { Nasional } & 3=\text { Internasional } \\ \text { Untuk nilai tambah: } & 1=\text { Rendah } & 2=\text { Tinggi } & 3=\text { Sangat tinggi }\end{array}$

Tabel 11. Potensi dan tingkat pemanfaatan sumberdaya ikan untuk komoditi unggulan di Provinsi Sumatera Selatan

\begin{tabular}{|c|l|r|r|r|r|r|c|}
\hline \multirow{2}{*}{ No } & \multirow{2}{*}{$\begin{array}{l}\text { Jenis } \\
\text { ikan }\end{array}$} & \multicolumn{1}{c|}{ Potensi } & f optimum & & \multicolumn{1}{c|}{ TAC } & C rata-rata & Tingkat \\
\cline { 3 - 8 } & MSY (ton) & (trip) & f aktual & (Ton) & (ton) & Pemanfaatan (\%) \\
\hline 1 & Udang & 6297,98 & 709952 & 308802 & 5038,39 & 4536,5 & 66,77 \\
\hline 2 & Rajungan & 1955,98 & 207849 & 91940 & 1564,78 & 1298,3 & 63,60 \\
\hline 3 & Manyung & 4488,06 & 358268 & 135713 & 3590,45 & 3308,9 & 65,02 \\
\hline & $\begin{array}{l}\text { Golok- } \\
\text { golok }\end{array}$ & 3718,69 & 286413 & 92520 & 2974,95 & 2514,7 & 58,42 \\
\hline
\end{tabular}

Berdasarkan Tabel 11, tingkat pemanfaatan per jenis ikan unggulan menunjukkan bahwa tingkat pemanfaatan berkisar antara $58,42 \%-66,77 \%$ Potensi jenis ikan komoditi unggulan tersebut juga masih memungkinkan dimanfaatkan dan dikembangkan dengan menyusun strategi pemanfaatan sumberdaya ikan yang optimum dari sisi alat tangkap (jenis dan selektivitas) dan pengelolaan sumberdaya tersebut. Sehingga dapat dimanfaatkan guna meningkatkan pendapatan nelayan dan tetap menjaga kelestarian sumberdaya ikan.

\subsection{Teknologi Penangkapan Ikan}

Analisis terhadap komoditi unggulan telah dilakukan dengan memperoleh jenis komoditinya dan potensi yang masih memiliki peluang pengembangannya pada masa yang akan datang. Selanjutnya dapat dilakukan analisis terhadap jenis teknologi yang memungkinkan digunakan dalam 
mendukung pemanfaatan sumberdaya ikan dominan di Provinsi Sumatera Selatan. Menurut Monitja (2000), pemilihan suatu teknologi penangkapan ikan yang tepat untuk diterapkan dalam pengembangan perikanan tangkap perlu mempertimbangkan: (1) teknologi yang ramah lingkungan; (2) teknologi yang secara teknis dan ekonomis menguntungkan; dan (3) teknologi yang berkelanjutan (Nurani, 2002).

Hasil analisis yang dilakukan pada lokasi penelitian menunjukkan bahwa teknologi penangkapan yang ada dan digunakan oleh para nelayan di Provinsi Sumatera Selatan masih menggunakan teknologi yang relatif sederhana seperti gillnet, trammel net, pancing, perangkap. Teknologi pilihan dianalisis berdasarkan beberapa aspek yaitu aspek biologi, teknis, sosial dan ekonomi, sehingga teknologi yang terpilih merupakan teknologi yang tepat berdasarkan aspek tersebut. Berdasarkan pada Tabel 12, terlihat bahwa jenis alat tangkap trammel net, jaring insang hanyut dan bagan tancap merupakan jenis alat tangkap yang memiliki prioritas terbaik untuk dikembangkan dibandingkan dengan jenis alat tangkap lainnya. Hal ini terbukti dari jumlah armada dan produksi hasil tangkapan dimana ketiga jenis alat tangkap ini sangat banyak dan memungkinkan digunakan di sekitar perairan Sumatera Selatan. Dari segi pengoperasian yang mudah, biaya investasi rendah, daerah penangkapan, penggunaan tenaga kerja serta keuntungan yang diperoleh yang membuat jenis alat tangkap ini banyak digunakan oleh para nelayan di sekitar perairan Sumatera Selatan.

Jika dilihat dari efektivitas alat tangkap dominan tersebut, masih perlu adanya pengembangan teknologi di bidang selektivitas, dimana beberapa jenis ikan tertangkap oleh alat tangkap yang sama, ukuran dari jenis ikan tidak terseleksi berdasarkan alat tangkap. Sehingga, jika tidak adanya pengembangan teknologi penangkapan, maka dikhawatirkan akan terjadinya degradasi sumberdaya ikan yang signifikan di sekitar perairan Sumatera Selatan.

Tabel 12. Matriks keragaman teknologi penangkapan ikan terpilih dari unit penangkap ikan untuk komoditi unggulan di perairan Sumatera Selatan

\begin{tabular}{|c|c|c|c|c|c|c|c|c|c|}
\hline \multirow{2}{*}{ No } & \multirow{2}{*}{ Unit Penangkapan Ikan } & \multicolumn{8}{|c|}{ Aspek Penilaian } \\
\hline & & $\mathrm{X} 1$ & UP & $\mathrm{X} 2$ & UP & $\mathrm{X3}$ & UP & $\mathrm{X} 4$ & UP \\
\hline 1 & Bagan tancap & 0,50 & 5 & 4,54 & 1 & 1,52 & 3 & 3,39 & 2 \\
\hline 2 & Perangkap & 1,67 & 3 & 0,32 & 8 & 0,85 & 6 & 1,70 & 8 \\
\hline 3 & Jaring klitik & 2,17 & 2 & 0,91 & 6 & 0,70 & 8 & 3,61 & 3 \\
\hline 4 & Jaring insang tetap & 2,17 & 2 & 1,07 & 5 & 1,71 & 2 & 1,86 & 7 \\
\hline 5 & Pancing & 2,50 & 1 & 2,24 & 3 & 0,82 & 7 & 2,81 & 6 \\
\hline 7 & Trammel net & 1,00 & 4 & 1,50 & 4 & 1,89 & 1 & 5,81 & 1 \\
\hline 8 & Jaring lingkar & 0,33 & 6 & 0,60 & 7 & 1,00 & 5 & 1,60 & 9 \\
\hline 9 & Jaring insang hanyut & 1,00 & 4 & 4,29 & 2 & 1,35 & 4 & 3,32 & 5 \\
\hline & $\min$ & 0,333 & & 0,3180183 & & 0,70 & & 1,5976411 & \\
\hline & $\max$ & 2,5 & & 4,5439537 & & 1,89 & & 5,813773 & \\
\hline \multicolumn{10}{|c|}{ Standardisasi Teknolgi Penangkapan Terpilih } \\
\hline \multirow[b]{2}{*}{ No } & \multirow{2}{*}{ Unit Penangkapan Ikan } & \multicolumn{4}{|c|}{ Kriteria Penilaian } & \multirow{2}{*}{\multicolumn{2}{|c|}{ Total }} & \multirow{2}{*}{\multicolumn{2}{|c|}{ UP }} \\
\hline & & $\mathrm{V} 1(\mathrm{X} 1)$ & $\mathrm{V} 2(\mathrm{X} 2)$ & V3(X3) & $\mathrm{V} 4(\mathrm{X} 4)$ & & & & \\
\hline 1 & Bagan tancap & 0,08 & 1,00 & 0,69 & 0,42 & \multicolumn{2}{|c|}{2,193} & \multicolumn{2}{|c|}{3} \\
\hline 2 & Perangkap & 0,62 & 0,00 & 0,13 & 0,02 & \multicolumn{2}{|c|}{0,770} & \multicolumn{2}{|c|}{7} \\
\hline 3. & Jaring klitik & 0,85 & 0,14 & 0,00 & 0,48 & \multicolumn{2}{|c|}{1,463} & \multicolumn{2}{|c|}{6} \\
\hline 4 & Jaring insang tetap & 0,85 & 0,18 & 0,84 & 0,06 & \multicolumn{2}{|c|}{1,929} & \multicolumn{2}{|c|}{4} \\
\hline 5 & Pancing & 1,00 & 0,45 & 0,10 & 0,29 & \multicolumn{2}{|c|}{1,846} & \multicolumn{2}{|c|}{5} \\
\hline 7 & Trammel net & 0,31 & 0,28 & 1,00 & 1,00 & \multicolumn{2}{|c|}{2,587} & \multicolumn{2}{|c|}{1} \\
\hline 8 & Jaring lingkar & 0,00 & 0,07 & 0,25 & 0,00 & \multicolumn{2}{|c|}{0,320} & \multicolumn{2}{|c|}{8} \\
\hline 9 & Jaring insang hanyut & 0,31 & 0,94 & 0,55 & 0,41 & \multicolumn{2}{|c|}{2,207} & \multicolumn{2}{|c|}{2} \\
\hline
\end{tabular}

Sumber : hasil analisis

Keterangan :

$\mathrm{X} 1=$ Aspek biologi

$\mathrm{X} 3=$ Aspek sosial

$\mathrm{UP} \quad=\quad$ Urutan prioritas

$\mathrm{V} 2(\mathrm{X} 2)=$ Standardisasi aspek teknis

$\mathrm{V} 4(\mathrm{X} 4)$ $\begin{array}{ll}= & \text { Standardisasi } \\ = & \text { Standardisasi }\end{array}$ ekonomi
$\mathrm{X} 2=$ Aspek teknis

$\mathrm{X} 4=$ Aspek ekonomi

$\mathrm{V} 1(\mathrm{X} 1)=$ Standardisasi aspek biologi

$\mathrm{V} 3(\mathrm{X} 3)=$ Standardisasi aspek sosial 


\section{KESIMPULAN DAN SARAN}

\subsection{Kesimpulan}

1. Jenis komoditi unggulan di Provinsi Sumatera Selatan adalah jenis udang, kepiting, manyung, dan golok-golok.

2. Potensi jenis komoditi unggulan dengan tingkat pemanfaatan antara $58,42 \%$ $66,77 \%$, sehingga masih memiliki peluang untuk dikembangkan.

3. Jenis alat tangkap, trammel net, jaring insang hanyut, dan bagan tancap merupakan jenis alat tangkap unggulan yang dapat dikembangkan di Provinsi Sumatera Selatan.

\subsection{Saran}

Perlu dilakukan kajian lebih mendalam terhadap jumlah alat tangkap dan armada perikanan yang optimal dan strategi pengelolaan agar sumberdaya perikanan dapat dimanfaatkan secara optimal dan berkelanjutan.

\section{DAFTAR PUSTAKA}

Aziz, K.A., 1989. Pendugaan Stok Populasi Ikan Tropis. Departemen Pendidikan dan Kebudayaan. Pusat Antar Universitas Ilmu Hayat, IPB. Bogor, 89 hal.

Gulland, J.A., 1991. Fish Stock Assessment. A Manual of Basic Methods. John Wiley \& Sons. Chichester-New YorkBrisbane-Toronto-Singapore. 223 p.

Komisi Nasional Pengkajian Stok Sumberdaya Ikan. 1997. Potensi Sumberdaya Ikan dan Jumlah Tangkapan yang diperbolehkan (JTB) di Perairan Indonesia Tahun 1997. Jakarta: Komisi Nasional Pengkajian Stok Sumberdaya Ikan.

Mangkusubroto, K., C.1.Trisnadi. 1985. Analisa Keputusan. Pendekatan sistem dalam Manajemen usaha dan Proyek. Ganeca Exact, Bandung.
Monintja, D.R. 2000. Pelatihan Untuk Pelatih Pengelolaan Wilayah Pesisir Terpadu. Prosiding Pusat Kajian Sumberdaya Pesisir dan Lautan; Bogor. Bogor: Institut Pertanian Bogor. H1: 156.

Monintja, D.R. 2000. Strategi Pengembangan Sumberdaya Perikanan Tangkap Berbasis Ekonomi Kerakyatan. Seminar Nasional Strategi Pengembangan Sumberdaya Perikanan dan Kelautan Berbasis Kerakyatan. Riau 2003. hal:12.

Nurani, T.W. 2002. Aspek Teknis dan Ekonomi Pemanfaatan Lobster di Pangandaran Jawa Barat. Bulletin $P S P$, Vol. XI No.2. Jurusan Pemanfaatan Sumberdaya Perikanan. Institut Pertanian Bogor. Bogor. Hal:2946.

Tampubolon, G.H dan P. Sutedjo. 1983. Laporan Survei Analisa Potensi Penangkapan Sumberdaya Perikanan di Perairan Selat Malaka. Direktorat Jenderal Perikanan. Balai Penelitian dan Pengembangan Ikan. Semarang. 33 hal.

Zulkarnain dan Darmawan. 1997. Penggunaan Model Schaefer dan Model Fox untuk pendugaan Potensi dan Tingkat Pemanfaatan Sumberdaya Ikan Layang (Decapterus sp) di Perairan Eretan Wetan, Indramayu, Bulletin $P S P$, Vol. VI No.3. Jurusan Pemanfaatan Sumberdaya Perikanan. Institut Pertanian Bogor. Bogor. Hal: 3140. 